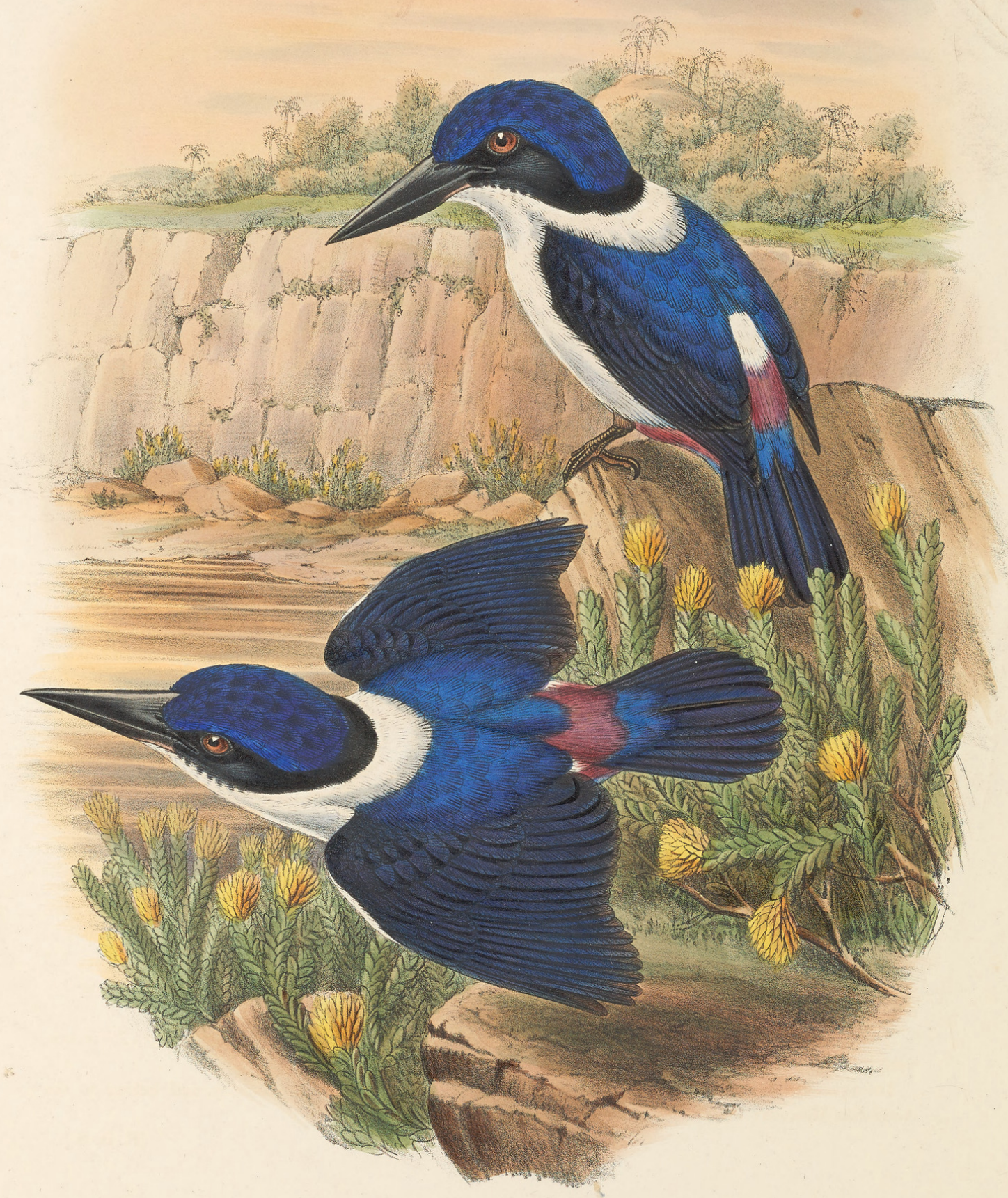

HHATAYON IIEUCOPYCITA 


\section{HALCYON LEUCOPYGIA.}

White-backed Kingfisher.

Cyanalcyon leucopygius, Verr. Rev. et Mag. de Zool. 1858, p. 385.-Salvad. Ann. Mus. Civic. Genov. x. p. 305 (1877).

Halcyon leucopygia, Gray, Cat. B. Trop. Isl. Pacific Ocean, p. 7 (1859).-Sclater, Proc. Zool. Soc. 1869, p. 119.Gray, Hand-l. B. i. p. 92, no. 1109 (1869).-Sharpe, Monogr. Alced. pl. 74 (1871).-Ramsay, Proc. Linn. Soc. N. S. W. iv. p. 67 (1879)._Salvad. Ibis, 1880, p. 127.

Todirhamphus leucopygius, Sclater, Proc. Zool. Soc. 1869, p. 124.

Cyanalcyon leucopygia, Salvad. Ann. Mus. Civic. Genov. x. p. 305 (1877).-Id. Orn. Papuasia, etc. i. p. 456 (1880).

This beautiful Kingfisher was until recently one of the rarest of the family in European collections; for when the 'Monograph of the Kingfishers' was written but one specimen, the type in the British Museum, was known to naturalists, and this was figured in the work above mentioned. Since then the only naturalist who has met with the species in its native haunts has been Mr. Cockerell, who procured a large series in Guadalcanar in the Solomon Archipelago. His collection was described by Mr. Ramsay, who was the first to point out the difference in the colouring of the sexes, the white back, from which the species derives its name, being apparently the sign of the male, as the female has the lower back beautiful blue. The lilac colour which is so distinct on the sides of the lower back in both sexes will always be considered one of the peculiar characters of this fine species of Halcyon.

Nothing has been recorded concerning the habits of this species, which, so far as we know, is only found in the Solomon group of islands.

The following is the description of the type specimen, transcribed from the 'Monograph':-

Adult male. Head, scapulars and wing-coverts, and upper part of the back rich ultramarine; a collar round the neck, the entire back except the interscapulary portion, and the under surface of the body pure white; cheeks black; upper tail-coverts ultramarine; lower part of the flanks bordering the rump and vent lilac shaded with purple; quills and tail black, washed with blue above, greyish black underneath; bill entirely black; feet olive-brown. Total length $8 \cdot 2$ inches, of bill from front $1 \cdot 6$, from gape $2 \cdot 1$, wing $3 \cdot 3$, tail $2 \cdot 5$, tarsus $0 \cdot 5$.

Adult female. Similar to the male, but having the lower back blue instead of white. Total length $7 \cdot 5$ inches, wing $3 \cdot 3$, tail $2 \cdot 3$, tarsus $0 \cdot 5$.

The figures in the Plate are drawn from a pair lent to us by Mr. E. P. Ramsay, and belong to the Australian Museum; they represent the male and female of the natural size. 


\section{$2 \mathrm{BHL}$ Biodiversity Heritage Library}

Gould, John and Sharpe, Richard Bowdler. 1884. "Halcyon leucopygia, White-backed Kingfisher [PI. 55]." The birds of New Guinea and the adjacent Papuan islands : including many new species recently discovered in Australia 4(XVIII), -. https://doi.org/10.5962/p.322840.

View This Item Online: https://www.biodiversitylibrary.org/item/230755

DOI: https://doi.org/10.5962/p.322840

Permalink: https://www.biodiversitylibrary.org/partpdf/322840

\section{Holding Institution}

Smithsonian Libraries

\section{Sponsored by}

Biodiversity Heritage Library

\section{Copyright \& Reuse}

Copyright Status: Public domain. The BHL considers that this work is no longer under copyright protection.

This document was created from content at the Biodiversity Heritage Library, the world's largest open access digital library for biodiversity literature and archives. Visit BHL at https://www.biodiversitylibrary.org. 